\title{
Multilocus Characterization, Gene Expression Analysis of Putative Immunodominant Protein Coding Regions, and Development of Recombinase Polymerase Amplification Assay for Detection of 'Candidatus Phytoplasma Pruni' in Prunus avium
}

\author{
Dan Edward V. Villamor ${ }^{\dagger}$ and Kenneth C. Eastwell \\ Department of Plant Pathology, Washington State University Irrigated Agriculture Research and Extension Center, Prosser, WA 99350 \\ Accepted for publication 17 December 2018.
}

\begin{abstract}
Western X (WX) disease, caused by 'Candidatus Phytoplasma pruni', is a devastating disease of sweet cherry resulting in the production of small, bitter-flavored fruits that are unmarketable. Escalation of WX disease in Washington State prompted the development of a rapid detection assay based on recombinase polymerase amplification (RPA) to facilitate timely removal and replacement of diseased trees. Here, we report on a reliable RPA assay targeting putative immunodominant protein coding regions that showed comparable sensitivity to polymerase chain reaction (PCR) in detecting ' $\mathrm{Ca}$. Phytoplasma pruni' from crude sap of sweet cherry tissues. Apart from the predominant strain of ' $\mathrm{Ca}$. Phytoplasma pruni',

the RPA assay also detected a novel strain of phytoplasma from several WX-affected trees. Multilocus sequence analyses using the immunodominant protein A (idpA), imp, rpoE, secY, and $16 \mathrm{~S}$ ribosomal RNA regions from several ' $\mathrm{Ca}$. Phytoplasma pruni' isolates from WX-affected trees showed that this novel phytoplasma strain represents a new subgroup within the 16SrIII group. Examination of high-throughput sequencing data from total RNA of WX-affected trees revealed that the imp coding region is highly expressed, and as supported by quantitative reverse transcription PCR data, it showed higher RNA transcript levels than the previously proposed idpA coding region of ' $\mathrm{Ca}$. Phytoplasma pruni'.
\end{abstract}

Western X (WX) disease is one of the most devastating diseases of sweet cherry not only because of its negative impact on tree growth and yield but also, because affected trees produce bitter-flavored and significantly reduced size fruits that are nonmarketable. The causal agent of the disease was first described as a grafttransmissible agent of cherry buckskin in California (Rawlins and Homes 1931) and subsequently, as a virus-like agent of X disease in peach in Connecticut (Stoddard 1934, 1938). The disease is known to be caused by phytoplasma, a wall-less bacterium within the class Mollicutes (Douglas 1986; Granett and Gilmer 1971; Jones et al. 1974; Lee et al. 1992; MacBeath et al. 1972; Nasu et al. 1970), and it is vectored by several species of leafhoppers, including Colladonas clitellarius, Colladonas montanus, Colladonas geminatus, Euscelidius variegatus, Fieberiella florii, Graphocephala confluens, Gyponana lamina, Keonella confluens, Norvellina seminuda, Osbornellus borealis, Paraphlepsius irroratus, and Scaphytopius delongi (Scaphytopius acutus) (Kirkpatrick et al. 1990; Larsen and Whalen 1988; Mcclure 1980; Rice and Jones 1972; Rosenberger and Jones 1978).

Along with little cherry disease caused by little cherry virus 2 ampelovirus (LChV2), WX disease was the major cause of poor production in sweet cherry commercial orchards in Washington State in the 1940s. This situation provided the impetus for the implementation of a statewide disease eradication program that culminated in the establishment of a clean plant program for

${ }^{\dagger}$ Corresponding author: D. E. V. Villamor; dvvillam@uark.edu

Funding: This work was supported in part by Department of Plant Pathology, College of Agricultural, Human, and Natural Resource Sciences Agricultural Research Center project WNP00754 and funding from the Washington State Tree Fruit Research Commission and the USDA-APHIS National Clean Plant Network.

*The $\boldsymbol{e}$-Xtra logo stands for "electronic extra" and indicates that two supplementary figures and two supplementary tables are published online.

The author(s) declare no conflict of interest.

(c) 2019 The American Phytopathological Society temperate climate fruit crops that evolved into the National Clean Plant Network for Temperate Climate Fruit Trees. The immediate outcome of these two activities was the reclaiming of sweet cherry production in the state to profitable levels. Since then, the incidence of WX disease along with other sweet cherry virus diseases was kept to a minimum level unnoticed by most sweet cherry growers.

A resurgence in the appearance of small unmarketable fruit was observed in Washington sweet cherry orchards. Symptoms attributable to both LChV2 and WX occurred in proportionately 60 and $40 \%$ of diseased trees, respectively (K. C. Eastwell, unpublished data). In addition to vector control, removal of diseased trees and replanting of pathogen-free trees are the primary means of disease management. Our group developed a rapid detection assay based on reverse transcription recombinase polymerase amplification (RT-RPA) for LChV2 (Mekuria et al. 2014) to facilitate timely detection and removal of diseased trees. Here, we extended the development of a recombinase polymerase amplification (RPA) assay for the WX disease agent 'Candidatus Phytoplasma pruni' and showed that the assay had comparable detection levels with the current polymerase chain reaction (PCR) assay for the phytoplasma. Serendipitously, our decision to use the two immunodominant protein coding regions immunodominant protein A (idpA) and putative imp of ' $\mathrm{Ca}$. Phytoplasma pruni' (Blomquist et al. 2001) as target regions for the RPA led to two discoveries: (i) identification of a novel phytoplasma strain representing a new subgroup within the $16 \mathrm{Sr}$ group III that is associated with WX disease and (ii) higher imp RNA transcript levels over the corresponding $i d p A$, suggesting that Imp is the major immunodominant protein of ' $\mathrm{Ca}$. Phytoplasma pruni' and not the previously characterized IdpA as formerly thought.

\section{MATERIALS AND METHODS}

Sample origin, designation, and nucleic acid extraction. Table 1 summarizes the designation of various samples used in this study. Shoots (lignified wood containing leaves and buds) from 
three major scaffold limbs were collected from a symptomatic tree (10-1) in August 2014. Similar tissue type was collected from three WX-infected trees (13-1, 15-1, and 15-4) from the same orchard in August 2016. Total RNA was extracted from leaves, bark scrapings, and buds from these samples (at 1:5 wt/vol tissue to buffer ratio) using the RNEasy mini kit (Qiagen) with modifications as described previously (Kappagantu et al. 2017a), except that residual DNA was removed from total RNA preparations after the DNase digestion of sample before the RNA clean-up protocol as described by the manufacturer. RNA from these samples was used for RNA expression analysis of idpA and the putative imp based on highthroughput sequencing (HTS) and quantitative reverse transcription polymerase chain reaction (qRT-PCR).

Leaf samples with intact petioles from trees expressing symptoms of WX disease (symptomatic) and apparently WXnegative trees (nonsymptomatic) were collected from additional sweet cherry commercial orchards in Washington. Each sample consisted of seven leaves from an individual tree, and they divided into two: one portion was used for DNA extraction (at 1:5 wt/vol tissue to buffer ratio) using the DNEasy kit (Qiagen) and subsequent PCR test for WX phytoplasma, and the remaining portion was processed using the General Extraction Buffer 3 (GEB3; Agdia Inc.) as described previously (Mekuria et al. 2014) and used for RPA detection of ' $\mathrm{Ca}$. Phytoplasma pruni'. A subset of these samples as indicated in Table 1 was used for multilocus sequence analysis. Similar tissues (leaves with petioles) from various stone fruit virus isolates maintained in the screenhouses of the Clean Plant Center Northwest (CPCNW) at Washington State University in Prosser, Washington were obtained and processed as described above.

Different tissue types were also obtained from commercial orchards at monthly intervals for a period of 6 months (March to August 2015) from five known WX disease-affected trees. Tissues were processed for DNA and GEB3 extractions as described above and tested for the presence for ' $\mathrm{Ca}$. Phytoplasma pruni' by PCR and RPA, respectively.

Negative control samples were obtained from virus-tested scion cultivar Bing on seedling rootstock cultivar Mazzard maintained at the CPCNW.

RPA. Primers and probe sequences targeting the two immunodominant protein coding regions (idpA and putative imp) of ' $\mathrm{Ca}$. Phytoplasma pruni' were designed based on a published sequence available from GenBank (accession number AF533231) as well as corresponding sequences generated by HTS from two local WX disease isolates; consensus sequences from these isolates were obtained by mapping short sequence reads using the published sequence as reference. A region targeting the $i d p A$ sequence (WX-idpA 315F/502R) (Table 2) was initially chosen and used in 2015. In 2016, redesigned primers and probe targeting the putative imp region (WX-imp 239F/500R) (Table 2) were used for similar assays. RPA was conducted following the recommendation provided by the AmplifyRP Acceler8 Discovery Kit (Agdia), with final primer and probe concentrations of 420 and $120 \mathrm{nM}$, respectively, and $1 \mu \mathrm{l}$ of crude cherry sap (GEB3 extracted as described above). Reaction tubes were incubated for $20 \mathrm{~min}$ at $39^{\circ} \mathrm{C}$ and followed by lateral flow detection inside the AmplifyRP Amplicon Detection Chamber (Agdia).

Sanger sequencing and phylogenetic analysis. PCR amplicons generated by oligonucleotides P1-Tint (targeting ribosomal DNA), WX-idpA (idpA), WX-imp (putative imp), WXrpoE $(r p o E)$, and WX-secY $(\sec Y)$ from representative samples (Table 1) were purified using the QIAquick PCR Purification Kit (Qiagen) and sequenced in both directions using forward and reverse primers for each amplicon (ELIM Biopharmaceuticals, Inc., Hayward, CA).

TABLE 1. Designation and origin of samples

Sample designation and use in this study ${ }^{\mathrm{a}}$

\begin{tabular}{llll}
\hline & \multicolumn{2}{c}{ Sample designation and use in this study $^{\mathrm{a}}$} \\
\cline { 2 - 4 } Sample origin & $\begin{array}{c}\text { Initial RPA testing, HTS, } \\
\text { and qRT-PCR }\end{array}$ & WX RPA evaluation $^{\mathrm{c}}$ & Multilocus sequence analysis $^{\mathrm{d}}$ \\
\hline Moxee, WA & $9557-1$ to -4 & & $9557-1,-2,-3$, and -4 \\
Benton City, WA & $9573-1$ & $9534-1$ and -5 \\
Yakima, WA & & $61-2,61-18,67-3,67-5,147-6,145-1,147-$ & 9834 and 9588 \\
Mattawa, WA & $9563-6$ and -8 & $11,141-3,70-1$, CB-1, CB-2, CB-3, CB-4, & $147-6$ and -11
\end{tabular}

Granger, WA 10-1, 13-1, 15-1, and 15-4

Finley, WA

Selah, WA

East Wenatchee, WA

Omak, WA

Okanogan, WA

Wenatchee, WA
11, 141-3, 70-1, CB-1, CB-2, CB-3, CB-4, $10375-1$, and $10375-2$

9-1, 10-2, ${ }^{\mathrm{c}} 10-4,11-4,13-1,15-1,15-4,9-2{ }^{\mathrm{c}}$

$12-1,{ }^{\mathrm{c}} 12-2,{ }^{\mathrm{c}} 14-1,{ }^{\mathrm{c}}$ and $17-6^{\mathrm{c}}$

$9852-3,-6,-8$, and -10

9855 and $10317-1,-3$ to $-6,-8$, and -9

9868

9872-1 and -2

9904-1, -2, -5, -6, and -12 and 10366-11

9928-1, 9928-2, 9949-1, 9949-2, 9993-2, 9993-6, 10324-1, 10324-2, 10324-3, 10324-4, 10324-8, 10324-9, 10324-14, 10324-100, 10324-101, 10324-102, 10289-13, 10289-19, 10289-22, and 10289-25

10202-4, -5 , and -6 and 10344-3e

\section{$10-1,11-4,13-1,14-3,15-4$, and 16-3}

$9852-3,-6,-8$, and -10

10317-1, -9, and -11

$9583-7,-8,-9,-10,-11$, and -12

10366-11

9928-2, 9949-1, 9949-2, 10324-1, 10324-2, 10324-3, 10289-13, 10289-19, 10289-22, and 10289-25

10202-4, -5 , and -6 and 10344-3e 9886-2

a WX, Western X. Details of sample preparation are described in the materials and methods section. Samples used for recombinase polymerase amplification (RPA) were extracted using General Extraction Buffer 3 and the DNEasy kit, whereas samples used for quantitative reverse transcription polymerase chain reaction (qRT-PCR) and high-throughput sequencing (HTS) were extracted using the RNEasy mini kit followed by DNase digestion and RNA clean up, and those used for multilocus sequence analysis were extracted using the DNEasy kit. Note that some samples were used in multiple experiments. All samples are sweet cherry, except for one peach sample (10344-3).

b In this column, samples in bold were used in HTS, whereas nonbold samples were used in the initial RPA testing.

c In Granger, Washington, six samples (9-2, 10-2, 12-1, 12-2, 14-1, and 17-6) used in the 2016 evaluation were sampled twice (the first one from symptomatic limb and the second one from nonsymptomatic limb); Table 5 has results.

d In this column, samples in italics (9557-1 to -4, 9573-1 and -5, 10-1, and 9583-7 to -12), nonbold (9834, 9588, 147-6, 147-11, 9852-3, 9852-6, 9852-8, 9852-10, 9928-2, 9949-1, 9949-2, and 9886-2), and bold (11-4, 13-1, 14-3, 15-4, 16-3, 10317-1, 10317-9, 10317-11, 10366-11, 10324-1 to -3, 10289-13, 10289-19, 1028922, 10289-25, 10202-4 to -6, and 10344-3) samples originated from 2014, 2015, and 2016 collections, respectively.

e This sample is from a diseased peach tree showing typical symptoms of peach $\mathrm{X}$ disease. 
Nucleotide sequences from various PCR amplicons were assembled using the BioEdit program (Hall 1999). Primer sequences from the P1-Tint amplicon were removed, whereas the full coding regions of $i d p A$, putative imp, rpoE, and sec $Y$ from corresponding amplicons were obtained. Nucleotide sequences were used for multiple alignment using the MUSCLE (Edgar 2004) implementation of the MEGA program package, version 7 (Kumar et al. 2016). Phylogenetic trees were reconstructed using the neighbor-joining method with 1,000 bootstrap replicates; branches supported by bootstrap values $<60 \%$ were collapsed.

HTS, PCR, and qRT-PCR. Before submission of samples for HTS, DNase-digested total RNAs from samples 10-1, 13-1, 15-1, and 15-4 were subjected to PCR using primers for ribosomal RNA (rRNA; Phyto 399mod/1694), idpA (WX-idpA 324F/493R), and imp (WX-imp 241F/420R) regions; the lack of specific amplicon in PCR with these primers confirmed the removal of residual PCRamplifiable DNA from total RNA preparations. Two micrograms of DNase-digested total RNA from the above samples and a virustested 'Bing' were sent for library construction using the Illumina TruSeq Stranded Total RNA Sample Preparation Kit with Plant Ribo-Zero and 50-bp single-end read HTS on the Illumina HiSeq 2500 platform with multiplexing (Microarray and Genomic Analysis Core Facility, Huntsman Cancer Institute, University of Utah). Removal of adapters and barcode sequences and subsequent trimming based on quality scores were done using the CLC Genomics Workbench 9 (CLC Bio). Sequence reads corresponding to host sequences (draft of whole-genome sequence of Prunus avium available in the GenBank database, accession number BDGV00000000) were first removed using the read mapping software of the CLC Genomics Workbench (short-read mapping parameters: mismatch cost $=2$; insertion and deletion costs $=3$; length and similarity fractions $=0.9$ ). An average read length of 50 nucleotides was recovered for each sample, and the number of reads after trimming and host sequence reduction is summarized in Supplementary Table S1. RNA sequence analysis was performed in the CLC Genomics Workbench using the $i d p A$ and imp coding regions and subsequently, the 550 protein coding sequences annotated from the reference sequence of the full genome of ' $\mathrm{Ca}$. Phytoplasma pruni' available in the GenBank database (accession number NZ_LHCF00000000). To ensure more accurate values of expression, only genes with mapped reads in all four samples were reported. The parameters used were the same as in the read mapping for host sequence reduction given above. Given the low number of WX-mapped reads (relative to the total number of sequence reads), the expression values for each coding region were calculated in reads per kilobase (RPK) rather than number of reads per kilobase per million reads mapped.

Table 2 lists the sequences of primers and probe used in RPA, PCR/qRT-PCR, and multilocus sequence analysis. For multilocus sequence analysis, DNA from sweet cherry tissues was used as a template for PCR using primer pairs P1/Tint (for rRNA), WX 47F/ 2078R (for the full idpA coding region), WX 8013F/8978R (for the full coding region of putative imp), and WX 4000F/4845R (for the full coding region of rpoE). To obtain the $\sec Y$ full coding region, a nested PCR was used with L15F1A(III)/MapR1A(III) primers followed by secYF1(III)/secYR1(III) primers (Lee et al. 2010; Martini et al. 2007). PCR was performed for 40 cycles in a $25-\mu l$ reaction consisting of $1 \mu \mathrm{l}$ of DNA template, $2.5 \mu \mathrm{l}$ of PCR buffer (10× High Fidelity PCR buffer; Invitrogen; Thermo Fisher Scientific Inc.), $14 \mu \mathrm{g}$ of nonacetylated bovine serum albumin

TABLE 2. Primer and probe sequences used in this study ${ }^{\mathrm{a}}$

\begin{tabular}{|c|c|c|c|}
\hline Primer and probe name & Target region & Primer and probe sequence & Source \\
\hline \multicolumn{4}{|l|}{ Primers } \\
\hline WX-idpA $315 \mathrm{~F}$ & $i d p A$ & ATTAACGACCACCCAAAACATTCTGCAAGC & This study \\
\hline WX-idpA 502R & $i d p A$ & ATTGAGTTTGACCCATTATTTTGATGAACGC & This study \\
\hline WX-idpA 493R & idpA & GACCCATTATTTTGATGAACGC & This study \\
\hline WX-idpA $83 \mathrm{~F}$ & $i d p A$ & CTCATAATAAGGTGTTTGGAAATGGTAAAAATATC & This study \\
\hline T7-WX-idpA 83F & $i d p A$ & CTAATACGACTCACTATAGGCTCATAATAAGGTGTTTG & This study \\
\hline WX-idpA 726R & idpA & GCTTTTTGTCGTTGTGGCAGCAGTTTCAGA & This study \\
\hline WX-imp $239 \mathrm{~F}$ & imp & AAAGCAGCRGCATTGAAAAAAGTTGTTAAAAC & This study \\
\hline WX-imp 500R & imp & GTAACTACTKTTTGACAGATGTCTTTTGTAAC & This study \\
\hline WX-imp $241 \mathrm{~F}$ & imp & GCAGCGGCATTGAAAAAAGTTG & This study \\
\hline WX-imp 420R & imp & GCAGCGGCATTGAAAAAAGTTG & This study \\
\hline WX-imp 47F & imp & AAAATGGTAAAATAGTTCTTGGCG & This study \\
\hline WX-imp 507R & imp & AGATTGAGTAACTACTTTTTGACAG & This study \\
\hline T7-WX-imp 47F & imp & CTAATACGACTCACTATAGGAAAATGGTAAAATAGTTC & This study \\
\hline WX $8013 \mathrm{~F}$ & Full imp & CATCCAGAATTTTTATCTCGTCC & This study \\
\hline WX 8978R & Full $\mathrm{imp}$ & TTATACCCACGACAATATTACCC & This study \\
\hline Phyt 399mod & rRNA & GCCGCGTGAACGATGAATTA & Skrzeczkowski et al. 2001 \\
\hline Phyt 1694 & rRNA & ATCAGGCGTGTGCTCTAACC & Skrzeczkowski et al. 2001 \\
\hline P1 & rRNA & AAGAGTTTGATCCTGGCTCAGGATT & Deng and Hiruki 1991 \\
\hline Tint & rRNA & TCAGGCGTGTGCTCTAACCAGC & Smart et al. 1996 \\
\hline L15F1A(III) & Partial spc operon & CTTCTGGTAAAGGACATAAAGG & Lee et al. 2010 \\
\hline MapR1A(III) & Partial spc operon & GGTTCTTCGTGCAATTGCAAACC & Lee et al. 2010 \\
\hline SecYF1(III) & $\sec Y$ & CTAGACCAGGTTTTGAAGG & Lee et al. 2010 \\
\hline SecYR1(III) & $\sec Y$ & GACCTGCTTTTCTCATTATAGC & Lee et al. 2010 \\
\hline \multicolumn{4}{|l|}{ Probes } \\
\hline WX-idpA probe & $i d p A$ & /5FAM/ & This study \\
\hline & & $\begin{array}{l}\text { TGGTGAAAGAAATACAAGATCAAAAACCGAATT/idSp/ } \\
\text { TTTAAGTGATGCTTCAA/3Phos/ }\end{array}$ & \\
\hline
\end{tabular}

a rRNA, ribosomal RNA; WX, Western X. 
(BSA), $200 \mathrm{nM}$ corresponding forward and reverse primers, $200 \mu \mathrm{M}$ dNTPs, $1.5 \mathrm{mM} \mathrm{MgCl}_{2}$, and $1 \mathrm{U}$ of Platinum Taq DNA Polymerase High Fidelity (Invitrogen; Thermo Fisher Scientific Inc.).

PCR amplicon targets were generated by WX-idpA 83F/726R and WX-imp 47F/507R for $i d p A$ and $i m p$, respectively. To compare the sensitivity of RPA and PCR, the $i d p A$ (WX-315F/502R) and imp (WX-imp 239F/500R) primers were used in both assays using dilutions of the corresponding purified PCR amplicons in either water or crude sap cherry extract. For comparative detection between PCR and RPA during the growing season, primers Phyto 399mod/1694 and WX-idpA 315F/502R were used in combination with Platinum Taq DNA Polymerase (Invitrogen) instead of the high-fidelity equivalent.

DNase-digested total RNA samples 10-1, 13-1, 15-1, and 15-4 previously sent for HTS were also used as templates for qRT-PCR. Templates used as negative controls included water and DNasedigested total RNA from virus-tested 'Bing' on 'Mazzard' seedling rootstock. qRT-PCR reactions were performed in a real-time thermocycler (Rotor-Gene 6000 instrument equipped with 6000 series software, version 7; Corbett Research). The following settings were used: capture of fluorescent readings at $520 \mathrm{~nm}$, gain setting of seven, and excitation and emission wavelengths of EvaGreen (Biotium) at 500 and $530 \mathrm{~nm}$, respectively. Absolute quantification of the $i d p A$ and imp messenger RNA (mRNA) expression levels was estimated using standard curves prepared from in vitro transcribed RNA from corresponding idpA and imp PCR amplicons containing the minimal T7 promoter sequence; these amplicons (644 nucleotides for $i d p A$ using T7-WX-idpA 83F/ WX-idpA 726R primers and 461 nucleotides for imp using T7-WXimp 47F/WX-imp 500R primers) span the expected qRT-PCR amplicons for each region. Standard curves were generated using 10 fivefold serial dilutions (starting at $5 \mathrm{ng}$ ) of in vitro transcribed RNA for each region. qRT-PCR was performed in a $25-\mu l$ reaction consisting of $1 \mu \mathrm{l}$ RNA template and $24 \mu \mathrm{l}$ master mix $(12.5 \mu \mathrm{l}$ of $2 \times$ buffer [Ambion; Thermo Fisher Scientific], $7.75 \mu$ l RNase-free water, $0.25 \mu \mathrm{l}$ from $20 \mu \mathrm{M}$ stock of each forward and reverse primer [for idpA: WX-idpA 324F and WX-idpA 493R; for imp: WX-imp $241 \mathrm{~F}$ and WX-imp 420R], $2 \mu \mathrm{l}$ of $7.5 \mu \mathrm{g}$ nonacetylated BSA, $1 \mu \mathrm{l}$ Superscript III reverse transcription and Platinum Taq polymerase [Invitrogen], and $1.25 \mu \mathrm{l}$ of $20 \times$ EvaGreen [Biotium]). First-strand complementary DNA synthesis was carried out for $30 \mathrm{~min}$ at $55^{\circ} \mathrm{C}$ followed by PCR at $94^{\circ} \mathrm{C} ; 2$ min initial denaturation; 35 cycles of $94^{\circ} \mathrm{C}$ for $15 \mathrm{~s}, 55^{\circ} \mathrm{C}$ for $20 \mathrm{~s}$, and $68^{\circ} \mathrm{C}$ for $30 \mathrm{~s}$; and a final extension for $5 \mathrm{~min}$ at $68^{\circ} \mathrm{C}$. RNA expression levels of the $i d p A$ and imp were extrapolated from the standard curve. Conversion from nanograms to number of copies per coding region was done using the following formula: [(amount of amplicon in nanograms) $(6.022 \times 1,023$ molecules per mole $)] /[($ length of dsDNA amplicon $\times 660 \mathrm{~g} / \mathrm{mole})$ $(1 \times 109 \mathrm{ng} / \mathrm{g})]$ (http://scienceprimer.com/copy-number-calculatorfor-realtime-pcr). The lengths of dsDNA amplicons were 170 and 180 nucleotides for $i d p A$ and $i m p$, respectively. Finally, the number of copies per coding region was divided by the amount of RNA in each sample to obtain copies per nanogram of plant RNA.

\section{RESULTS}

Development of RPA detection system for WX phytoplasma. Initial evaluation of RPA using idpA and putative imp primers on seven ' $C a$. Phytoplasma pruni'-positive trees yielded results that were comparable with PCR based on rRNA (primers Phyto $399 \mathrm{mod} / 1694 \mathrm{c}$; data not shown). The same idpA and putative imp primers, designed for RPA, detected ' $C a$. Phytoplasma pruni' in PCR. Sequence comparison of the target regions verified potential amplification in RPA and PCR formats (Supplementary Fig. S1A).

The WX RPA detection system based on idpA primers and probe was evaluated for its sensitivity, specificity, and reliability (measured in terms of capability to detect the pathogen throughout the growing season). In sensitivity assay, the WX RPA idpA detection system yielded comparable results with PCR (Table 3). For specificity, the WX RPA showed no background reaction on trees harboring viruses associated with similar symptoms as ' $\mathrm{Ca}$. Phytoplasma pruni', namely little cherry virus 1 (LChV1) and LChV2, and two bacterial pathogens, Pseudomonas syringae pv. syringae (bacterial canker pathogen) and ' $\mathrm{Ca}$. Phytoplasma pyri' (pear decline phytoplasma). Finally, temporal detection of ' $\mathrm{Ca}$. Phytoplasma pruni' from different tissues at six time points in the sweet cherry growing season (mid-March to mid-August) using infected trees from commercial orchards yielded comparable results with PCR (Table 4).

The WX RPA detection system based on the $i d p A$ region was further evaluated using leaf samples from different sweet cherry

TABLE 3. Comparison between polymerase chain reaction (PCR) and recombinase polymerase amplification (RPA) in detecting various concentrations of 'Candidatus Phytoplasma pruni' diluted in either water or crude sap from sweet cherry leaves

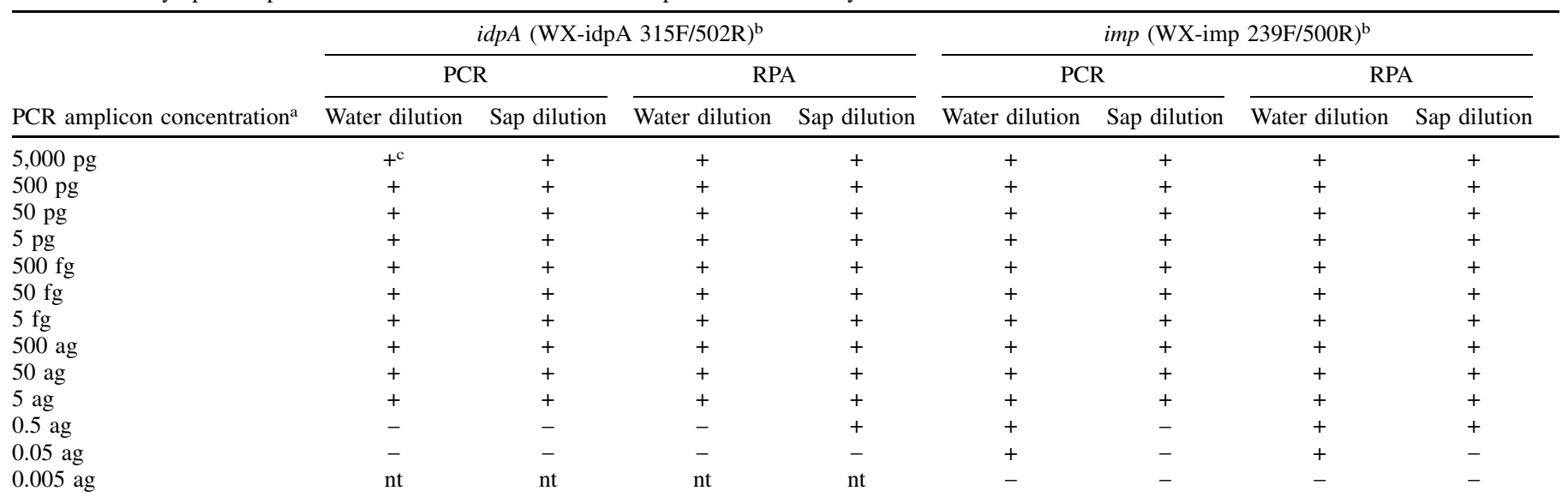

a Tenfold serial dilutions of PCR amplicons for each primer were made in either water or crude sweet cherry leaf sap after purification using the Qiaquick PCR purification Kit (Qiagen). The PCR amplicon for each primer consists of 644 and 461 bp for idpA (generated by Western X [WX]-idpA 83F/726R) and imp (generated by WX-imp 47F/507R), respectively. These amplicons are 5' and 3' longer but also span the corresponding expected amplicons of RPA primers for each region.

b The idpA (expected amplicon size: $187 \mathrm{bp}$ ) and imp (expected amplicon size: $261 \mathrm{bp)} \mathrm{primers} \mathrm{were} \mathrm{used} \mathrm{for} \mathrm{both} \mathrm{PCR} \mathrm{and} \mathrm{RPA.} \mathrm{For} \mathrm{both} \mathrm{water} \mathrm{and} \mathrm{crude} \mathrm{sap}$ dilutions, PCR was performed as described in the materials and methods section as well as using $1 \mu \mathrm{lof}$ template, 40 cycles, and $55^{\circ} \mathrm{C}$ annealing temperature for $30 \mathrm{~s}$ for both primers.

c Plus and minus indicate positive and negative results, respectively, whereas nt means not tested. 
growing regions in Washington State (Table 5). During the 2015 sweet cherry growing season, results of RPA and PCR testing were identical (31 positives and 5 negatives). However, during the initial stages of WX RPA testing the following year (2016 growing season), three samples (10289-13, -19, and -25) from symptomatic trees yielded negative results in RPA but positive results by PCR using rRNA primers Phyto 399mod/1694c. Sequencing of amplicons corresponding to the full coding regions of $i d p A$ and putative imp sequencing revealed 20 mismatches within the $i d p A$ primers and probe combination $(6,4$, and 10 mismatches for forward and reverse primers and probe, respectively), including a 3-nucleotide gap within the $i d p A$ forward primer. Notably, the putative imp primers and probe only had five mismatch sequences (one, three, and one for the forward and reverse primers and probe, respectively).

TABLE 4. Detection of 'Candidatus Phytoplasma pruni' from mid-March to mid-August 2015 using Western X (WX)-affected trees from commercial orchards

\begin{tabular}{|c|c|c|c|c|c|c|c|c|c|c|c|c|}
\hline \multirow[b]{2}{*}{ Month } & \multicolumn{6}{|c|}{ RPA using crude sapa } & \multicolumn{6}{|c|}{ PCR using purified $\mathrm{DNA}^{\mathrm{a}}$} \\
\hline & lvs & bsc & fls & flp & frs & $\mathrm{gsh}$ & lvs & bsc & fls & flp & frs & gsh \\
\hline March & $1 / 3^{\mathrm{b}}$ & $2 / 3$ & $2 / 3$ & $0 / 3$ & - & - & $1 / 3$ & $3 / 3$ & $2 / 3$ & $0 / 3$ & - & - \\
\hline April & $3 / 3$ & $3 / 3$ & - & - & $3 / 3$ & - & $3 / 3$ & $3 / 3$ & - & - & $3 / 3$ & - \\
\hline May & $3 / 3$ & $3 / 3$ & - & - & $3 / 3$ & - & $3 / 3$ & $3 / 3$ & - & - & $3 / 3$ & - \\
\hline June & $3 / 3$ & $3 / 3$ & - & - & $3 / 3$ & $3 / 3$ & $3 / 3$ & $3 / 3$ & - & - & $3 / 3$ & $3 / 3$ \\
\hline July & $5 / 5^{\mathrm{c}}$ & $5 / 5$ & - & - & $5 / 5$ & $5 / 5$ & $5 / 5$ & $5 / 5$ & - & - & $5 / 5$ & $5 / 5$ \\
\hline August & $5 / 5$ & $5 / 5$ & - & - & - & - & $5 / 5$ & $5 / 5$ & - & - & - & - \\
\hline
\end{tabular}

a bsc, bark scraping; flp, flower petal; fls, flower stem; frs, fruit stem; gsh, green shoots; and lvs, leaves. Crude sap and purified DNA were obtained as described in the materials and methods section. For each month, the recombinase polymerase amplification (RPA)- and polymerase chain reaction (PCR)-positive (DNA from WX-affected tree) and -negative controls (non-WX-affected tree) resulted in positive and negative reactions, respectively. RPA was performed using the $i d p A$ primers (WX-idpA $315 \mathrm{~F} /$ 502R), whereas the ribosomal RNA primers Phyto $399 \mathrm{mod} / 1694 \mathrm{c}$ were used in PCR.

b From March to June, three samples (10-1, 14-3, and 16-3) were obtained from WX-affected trees from an orchard in Granger, Washington.

c From July to August, two additional samples (147-6 and 147-11) were obtained from WX-affected trees in an orchard in Mattawa, Washington.
Consequently, the WX-imp primers were redesigned, which resulted in detection of the ' $\mathrm{Ca}$. Phytoplasma pruni' variant from samples 10289-13, -19, and -25. Sensitivity evaluation of the redesigned imp primers yielded similar results to those obtained with the idpA region RPA and PCR assays (Table 3 and Supplementary Fig. S2). Moreover, the redesigned WX-imp primers did not produce background reactions on pear decline and peach yellow leafroll isolates of ' $\mathrm{Ca}$. Phytoplasma pyri' or on predominant sweet cherry viruses in Washington orchards. These viruses include LChV1, LChV2, cherry necrotic rusty motte virus, cherry rusty mottle-associated virus, cherry twisted leaf-associated virus, cherry green ring mottle virus, cherry mottle leaf virus, cherry leafroll virus, cherry raspleaf virus, prune dwarf virus, and prunus necrotic ringspot virus.

The WX RPA detection system was reevaluated in 2016 using redesigned imp primers and probe. Forty-seven samples yielded identical results with PCR (Table 5). Notably, seven samples (10-2, $10-4,11-4,13-1,15-1,15-4$, and 61-2) were collected from the identical trees used in the 2015 evaluation, because these trees were still present in the orchard at the time of testing. Results of the 2015 and 2016 RPA and PCR testing on these trees were identical, except for one tree (10-2) that showed RPA- and PCR-positive results in 2016 but negative RPA and PCR results in 2015. A close examination of this tree (10-2) in the orchard during the fall of 2016 (late August) revealed that only some of the major scaffold limbs were symptomatic, suggesting recent infection by the phytoplasma. Consequently, the symptomatic and nonsymptomatic limbs from the 10-2 tree were resampled individually along with five additional trees from the same orchard suspected of being recently infected (9-2, 12-1, 12-2, 14-1, and 17-6); both RPA and PCR testing yielded positive and negative results in all of the symptomatic and nonsymptomatic limbs of the six samples, respectively.

Multilocus sequence analysis. The discovery of unique disease isolates from three samples (10289-13, -19, and -25) that yielded negative results in RPA using $i d p A$ primers but positive results for RPA and PCR results using imp and rRNA primers, respectively, prompted additional investigation to elucidate the identity of this phytoplasma. A longer fragment of the rRNA

TABLE 5. Summary of Western X (WX) recombinase polymerase amplification (RPA) and polymerase chain reaction (PCR) tests results

\begin{tabular}{|c|c|c|c|c|c|c|}
\hline \multirow[b]{3}{*}{ Sample origin } & \multicolumn{6}{|c|}{ WX RPA evaluation } \\
\hline & \multicolumn{3}{|l|}{2015} & \multicolumn{3}{|l|}{2016} \\
\hline & Sample identification $^{\mathrm{a}}$ & $\mathrm{RPA}^{\mathrm{b}}$ & $\overline{\mathrm{PCR}^{\mathrm{b}}}$ & Sample identification $^{\mathrm{a}}$ & $\mathrm{RPA}^{\mathrm{b}}$ & $\mathrm{PCR}^{\mathrm{b}}$ \\
\hline Mattawa, WA & $\begin{array}{c}\text { 61-2, 61-18,67-3, 67-5, 147-6, 145-1, } \\
147-11, \text { and } 141-3\end{array}$ & $5 / 8$ & $5 / 8$ & $\begin{array}{c}61-2,70-1, \mathrm{CB}-1, \mathrm{CB}-2, \mathrm{CB}-3, \mathrm{CB}-4, \\
10375-1, \text { and } 10375-2\end{array}$ & $5 / 8$ & $5 / 8$ \\
\hline Granger, WA & $9-1, \underline{10-2,10-4,11-4,13-1,15-1, \text { and } 15-4}$ & $5 / 7$ & $5 / 7$ & $\begin{array}{l}\frac{10-4,11-4,13-1,15-1,15-4,9-2 \mathrm{~s}, 9-2 \mathrm{~ns}}{10-2 \mathrm{~s}, 10-2 \mathrm{~ns}, 12-1 \mathrm{~s}, 12-1 \mathrm{~ns}, 12-2 \mathrm{~s}, 12-} \\
\frac{1 \mathrm{~ns}}{1}, 14-1 \mathrm{~s}, 14-1 \mathrm{~ns}, 17-6 \mathrm{~s}, \text { and } 17-6 \mathrm{~ns}\end{array}$ & $\begin{array}{l}10 / \\
17\end{array}$ & $\begin{array}{l}10 / \\
17\end{array}$ \\
\hline Selah, WA & 9855 & $1 / 1$ & $1 / 1$ & $10317-1,-3$ to $-6,-8$, and -9 & $7 / 7$ & $7 / 7$ \\
\hline East Wenatchee, WA & 9868 & $1 / 1$ & $1 / 1$ & & & \\
\hline Omak, WA & $9872-1$ and -2 & $2 / 2$ & $2 / 2$ & & & \\
\hline Okanogan, WA & $9904-1,-2,-5,-6$, and -12 & $5 / 5$ & $5 / 5$ & $10366-11$ & $1 / 1$ & $1 / 1$ \\
\hline Wenatchee, WA & $\begin{array}{c}9928-1,9928-2,9949-1,9949-2,9993-2 \\
\text { and } 9993-6\end{array}$ & $6 / 6$ & $6 / 6$ & $\begin{array}{c}\text { 10324-1, 10324-2, 10324-3, 10324-4, } \\
10324-8,10324-9,10324-14,10324-100 \\
10324-101,10324-102, \mathbf{1 0 2 8 9 - 1 3}, \mathbf{1 0 2 8 9}- \\
\mathbf{1 9}, \mathbf{1 0 2 8 9 - 2 2} \text {, and 10289-25 }\end{array}$ & $\begin{array}{l}10 / \\
10\end{array}$ & $\begin{array}{l}10 / \\
10\end{array}$ \\
\hline
\end{tabular}

a Underlined samples (10-2, 10-4, 11-4, 13-1, 15-1, 15-4, and 61-2) were used in both 2015 and 2016 WX RPA evaluations. Samples that appear in bold (10289$13,-19,-22$, and -25 ) were evaluated only using purified DNA samples; these samples were positive in PCR using the Phyto $399 \mathrm{mod} / 1694 \mathrm{c}$ primers and RPApositive and -negative using the imp and idpA primers, respectively. Samples that have s and ns designations were obtained from symptomatic and nonsymptomatic branches, respectively, of a suspected WX-positive tree (for a total number of six trees, namely 9-2, 10-2, 12-1, 12-2, 14-1, and 17-6).

b PCR was performed using the Phyto 399mod/1694c primers, whereas the RPA assay used different primers (WX-idpA 315F/502R primers in 2015 and WX-imp 239F/500R primers in 2016). 
containing the F2nR2 fragment was obtained using the P1/Tint primers (Deng and Hiruki 1991; Smart et al. 1996) to determine the possible identity of this phytoplasma sequence. Using the $i$ PhyClassifier online tool developed previously for phytoplasma classification and taxonomic assignment (Zhao et al. 2009), the F2nR2 fragment from 10289-13, -19, and -25 shared closest similarity coefficient values with members of the ' $\mathrm{Ca}$. Phytoplasma pruni' 16SrIII strains. Within this group, the highest value of 0.97 corresponded to the strain PX11Ct1, a member of the 16SrIII-A subgroup (X disease group). This similarity coefficient value of 0.97 or lower suggests that the three isolates $(10289-13,-19$, and -25) are unique, and putatively make up a new subgroup of phytoplasma within the $16 \mathrm{SrIII}$ group. In silico examination using the $i$ PhyClassifier online tool identified a virtual restriction fragment-length polymorphism (RFLP) pattern generated by the Hae III restriction enzyme for these three samples that is distinct from all known members of the 16SrIII group (Fig. 1A). Additional analysis by pairwise sequence alignment of the $\mathrm{F} 2 \mathrm{nR} 2$ fragment to the corresponding region of ' $\mathrm{Ca}$. Phytoplasma pruni' reference sequence revealed single-nucleotide variations in four sites; all three samples (10289-13, -19, and -25) contained A, G, C, and C instead of G, A, T, and T nucleotides at positions 7, 44, 110, and 870, respectively (Fig. 1B). A previous study on ' $\mathrm{C}$ a. Phytoplasma pruni' reported two sequence-heterogeneous $16 \mathrm{~S}$ rRNA operons in some Connecticut strains of the phytoplasma (Davis et al. 2013); this finding was supported by the presence of two peaks in the chromatogram at the heterogenous site. In the case of 10289-13, -19 , and -25 , examination of the chromatograms in these four variable sites revealed a single peak (Fig. 1B), negating the possible presence of heterogeneous rRNA sequences on these sites.

Consequently, examination of sequence diversity of ' $\mathrm{Ca}$. Phytoplasma pruni' revealed clustering of all Washington isolates with the 16SrIII-A group with the exception of the three isolates
10289-13, -19 , and -25 , which grouped variably depending on the genomic regions analyzed. Using the imp phylograms, these three isolates grouped closest phylogenetically to $16 \mathrm{SrIII}-\mathrm{F}$; to $16 \mathrm{SrIII}-\mathrm{H}$ using the $r R N A$, idpA, and rpoE products; and to 16SrIII-A using the $\sec Y$ (Fig. 2). All ' $C a$. Phytoplasma pruni' Washington isolates showed a single peak of T nucleotide at position 706 of the F2nR2 fragment of the rRNA region, which is in contrast to the Connecticut isolates that have either $\mathrm{C}$ or $\mathrm{T}$ in this position (Davis et al. 2013). Additionally, all Washington isolates, except for 10289-13, -19, -25, and -22 , had a single peak of A nucleotide at position 478 of the F2nR2 fragment of the rRNA region, whereas all published sequences of isolates from 16SrIII-A (including little peach, peach red suture, and peach rosette phytoplasmas) had a corresponding $G$ nucleotide in this region (data not shown). These results suggest the presence of a third $16 \mathrm{~S}$ rRNA operon sequence, herein referred to as $\mathrm{rrnC}$, and it is represented by ' $\mathrm{Ca}$. Phytoplasma pruni' isolates from Washington (Fig. 2).

Comparison between idpA and imp mRNA expression. Examination of short sequence reads from the sample that was sent for HTS in 2014 (10-1) revealed an abundance of imp reads relative to $i d p A$ with a visual estimate of at least 10 -fold imp reads over $i d p A$. To validate this observation, three additional RNA samples from WX-affected trees were prepared and sent for HTS in 2016; these three WX-affected trees not only were obtained in the same timeframe (mid-August) but also, originated from the same orchard as sample 10-1 collected in 2014 .

Analysis of RNA expression by HTS revealed higher read counts for the imp than the idpA coding region (not significant) using paired $t$ test (two-tailed $P$ value $=0.0569$ ); this difference in expression levels translates to 17-fold higher RPK values of imp over idpA (Table 6) (imp/idpA RPK: 3,950/228 = 17.3). Validation by qRTPCR revealed a similar trend (although not significantly by paired $t$ test; two-tailed $P$ value $=0.0576$ ), with the imp transcript showing

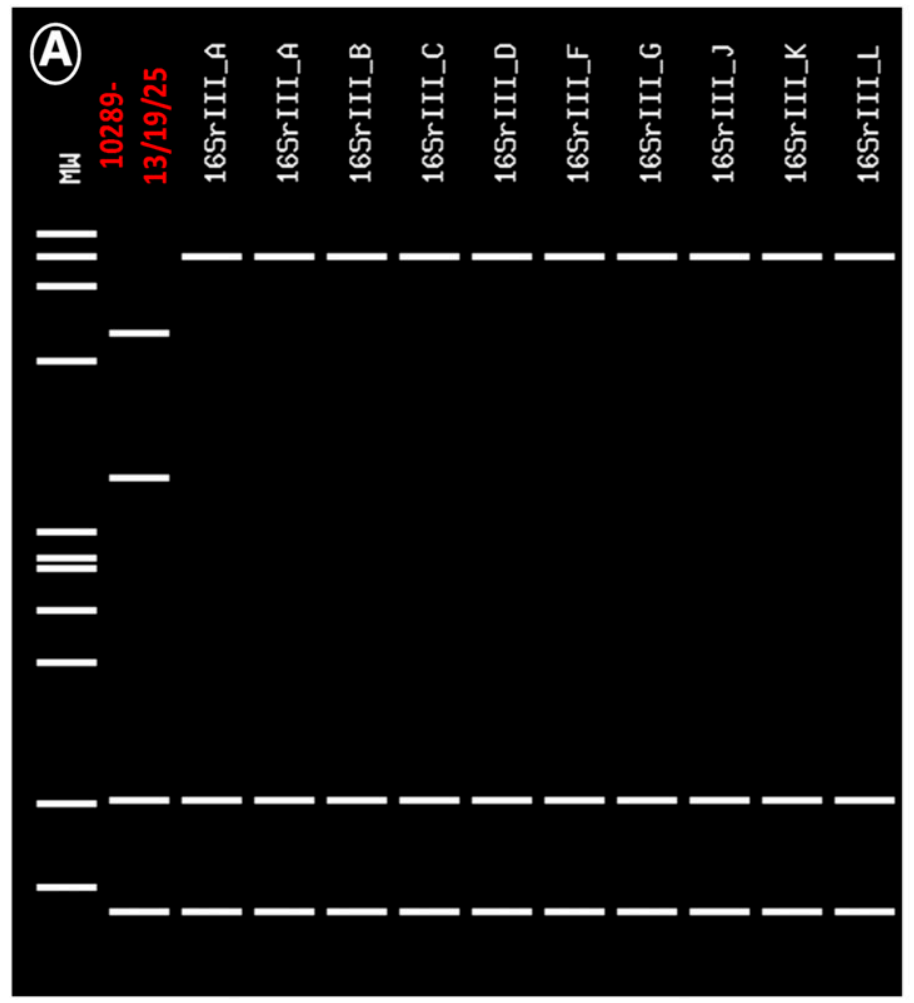

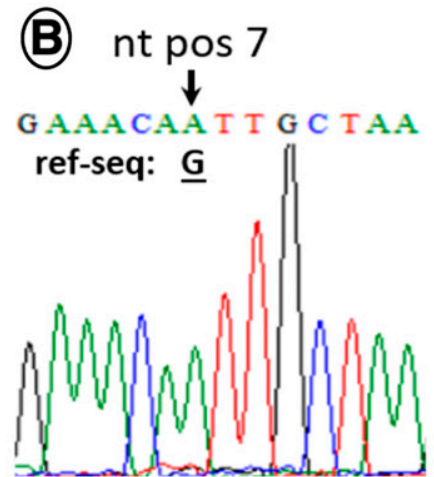

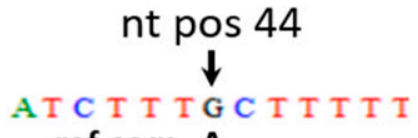

ref-seq: $\underline{A}$
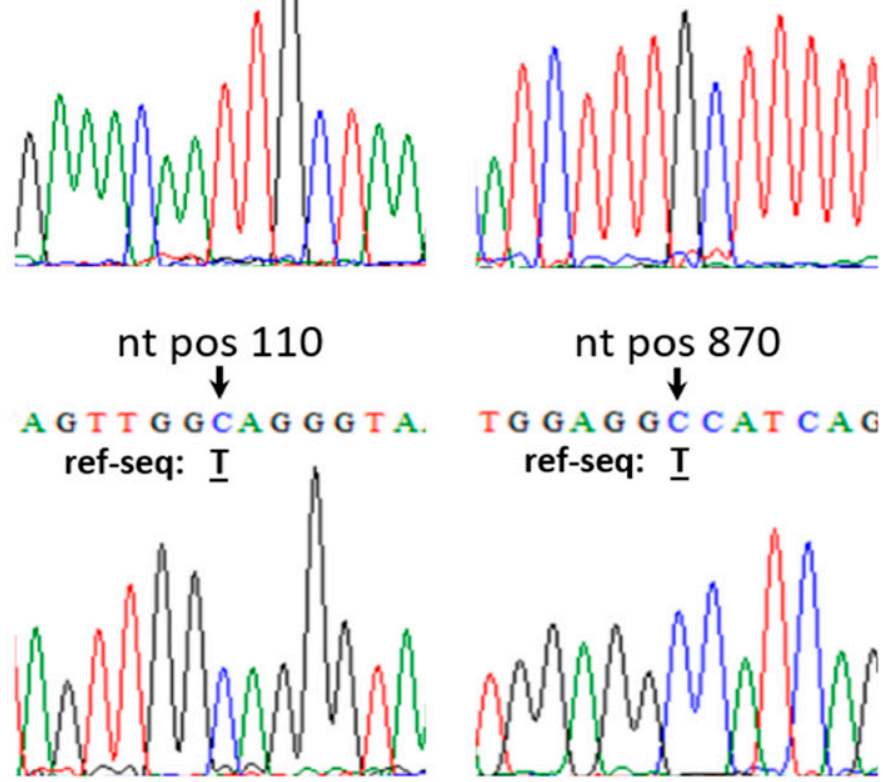

Fig. 1. A, Comparison of virtual restriction fragment-length polymorphism patterns of the F2nR2 fragment from 10289-13, -19, and -25 and representative isolates from 16SrXIII subgroups generated by $i$ PhyClassifier (Zhao et al. 2009) using HaeIII restriction enzyme; virtual digestion with HaeIII discriminates the strain from 10289-13, -19, and -25 from 16SrIII-A group (X disease group). B, Chromatogram from nucleotide sequencing of ribosomal RNA amplicons generated using P1/Tint primers from 10289-13, -19 , and -25 . Arrows show a single base call and the four variant nucleotide sites (using 'Candidatus Phytoplasma pruni' as the reference sequence) in the F2nR2 fragment of the P1/Tint amplicon. 
at least 18-fold higher expression levels than the idpA transcript (Table 6) (imp/idpA copies per nanogram plant RNA: 13,780.56/ $738.8=18.6)$. Additionally, excluding the tRNA and rRNAs (5S, $16 \mathrm{~S}$, and 23S), the imp RNA expression level is the second most highly expressed transcript of ' $\mathrm{C} a$. Phytoplasma pruni', whereas $i d p A$ RNA expression level ranked 39th (Supplementary Table S2).

\section{DISCUSSION}

Apart from vector control and the use of commercially available resistant cultivars, management of endemic phytoplasma diseases, including virus diseases, is achieved effectively through eradication of infected plants and replanting with pathogen-tested planting
rRNA (P1-Tint):

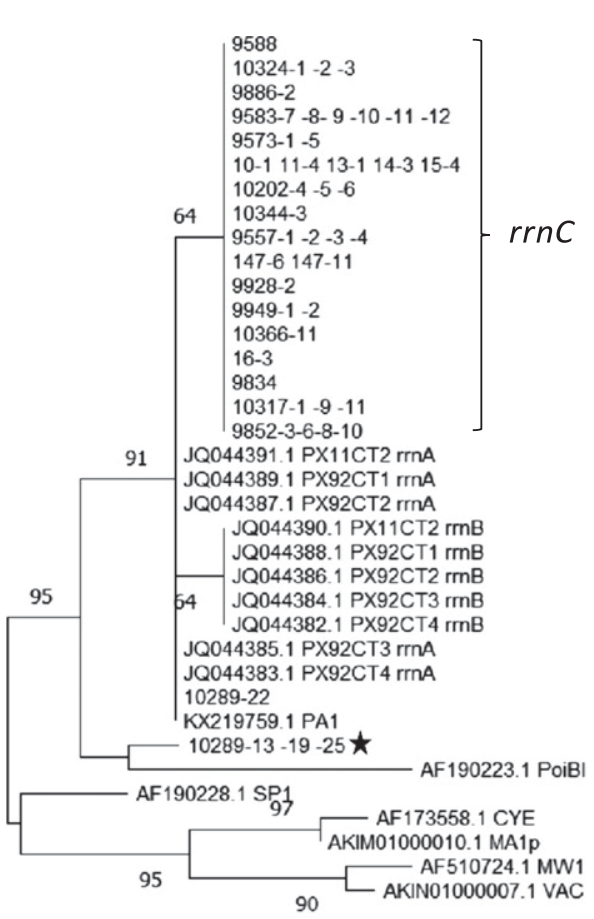

0.0010

idpA:

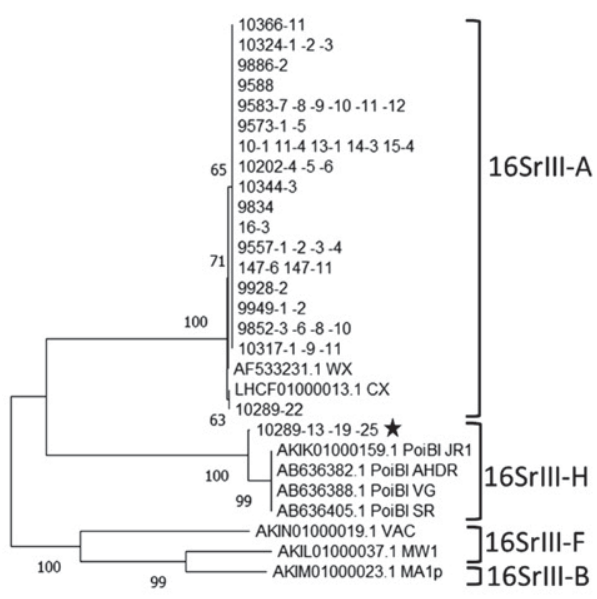

0.020

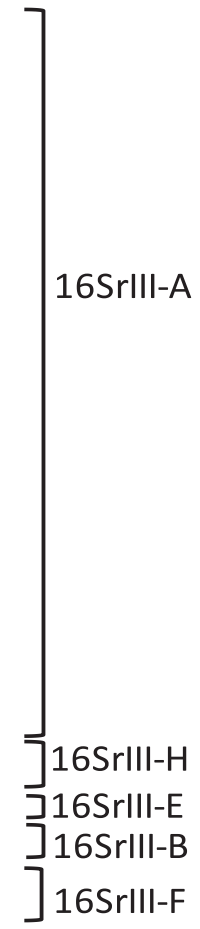

imp:
secY:

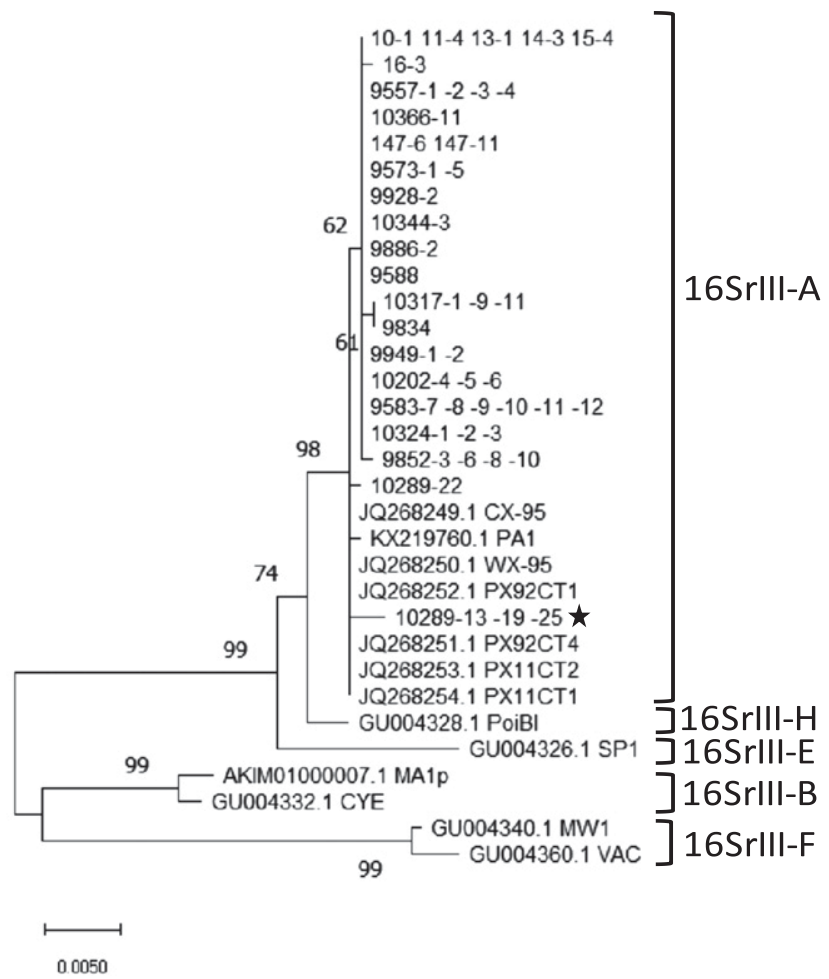

rpoE:
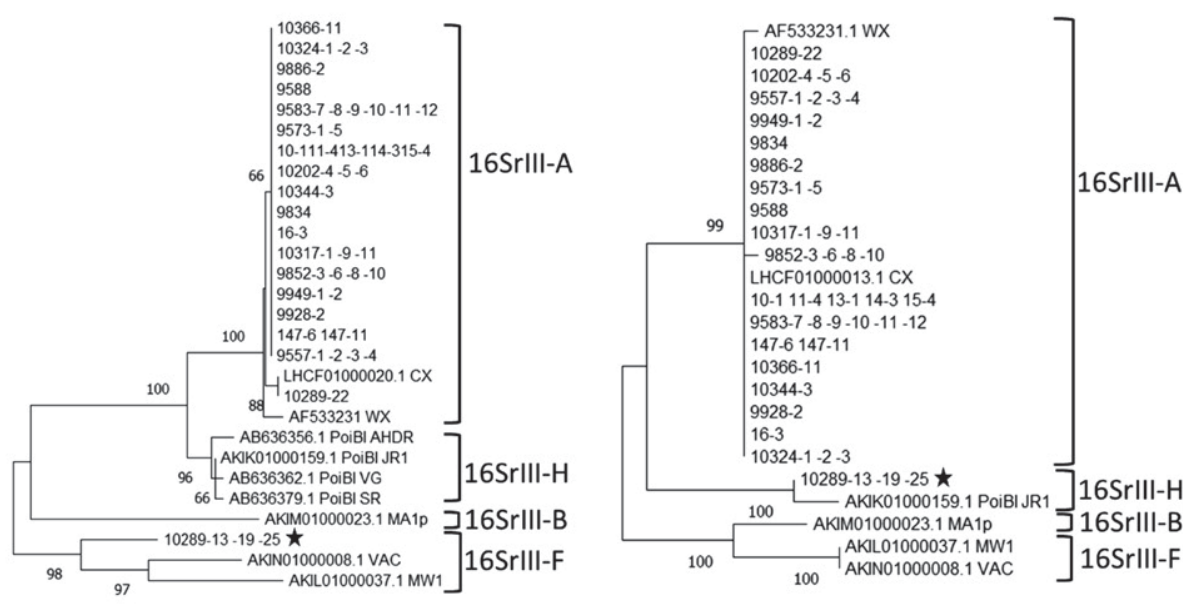

0.0050

Fig. 2. Phylogenetic trees deduced from analyses of the $16 \mathrm{~S}$ ribosomal RNA (rRNA; P1/Tint region), secY, immunodominant protein A (idpA), putative imp, and rpoE coding regions from different 16SrIII subgroups of 'Candidatus Phytoplasma pruni'. The GenBank accession numbers for sequences obtained in this study are MH809998 to MH810016, MH810017 to MH810035, MH810036 to MH810054, MH810055 to MH810073, and MH809979 to MH809997 for 16S rRNA, secY, idpA, putative imp, and rpoE, respectively. The trees were constructed with 1,000 bootstrap replicates using the neighbor-joining method in MEGA7. Branch nodes $>60 \%$ bootstrap values are shown. The suggested third $16 \mathrm{~S}$ rRNA operon within 16SrIII-A, rrnC, occupied by Washington isolates is indicated in the $16 \mathrm{~S}$ rRNA phylogram (P1-Tint region). The putative novel 'Ca. Phytoplasma pruni' strain from 10289-13, -19, and -25 is indicated by the star in each phylogram. CYE, clover yellow edge; MA1p, Italian clover phyllody; MW1, milkweed yellows; PoiBI, poinsettia branch inducing; SP1, Spirea stunt; VAC, Vaccinium witches broom. 
stocks. Critical to the timely implementation of these two activities is the availability of a rapid and accurate detection assay for a given pathogen. The incidences of little cherry disease caused primarily by LChV2 and WX disease caused by ' $C a$. Phytoplasma pruni' increased at epidemic proportions in Washington orchards. In this regard, a rapid RT-RPA assay for LChV2 was developed (Mekuria et al. 2014). In this study, RPA detection for ' $C a$. Phytoplasma pruni' was developed using the immunodominant protein coding region as the target region of choice. Because this region is highly variable within a single group of phytoplasma (i.e., the $16 \mathrm{SrIII}$ group) (Kakizawa et al. 2009), there is great potential for assay specificity within similar strains but not between subgroups (Wambua et al. 2017). Here, RPA's specificity to detect its cognate target and comparable sensitivity with the current molecular PCR detection method were shown. However, the most distinguishing characteristic of this assay system is its rapidity and simplicity over current methods, an important feature that makes it suitable for use in field offices or even on-farm sites (Kappagantu et al. 2017a, 2017b; Mekuria et al. 2014; Wambua et al. 2017)

The decision to extend the evaluation of the RPA assay on fieldinfected samples to two growing seasons (2 years) was based on previous experience in the development of the LChV2 RT-RPA assay that resulted in missed detection of known positive samples in actual field application. About $30 \%$ of the failed detection was attributed to the presence of a unique variant of LChV2 that was not identified from the virus population structure analysis during the developmental stage of the assay system; the former LChV2 RTRPA kit was eventually redesigned to accommodate detection of the unique virus variant (K. C. Eastwell, unpublished data). A similar occurrence was observed with the RPA assay for ' $\mathrm{Ca}$. Phytoplasma pruni', albeit to a lesser degree, because only three WX-positive trees (10289-13, -19, and -25) were not positively detected by RPA using the $i d p A$ primers. The redesigned RPA assay was based on the imp region as the target gene, which showed parallel specificity and sensitivity with the $i d p A$ primers. Although it was not possible to retest the crude sap extracts from the first-year sample (2015) with the imp primers in RPA, Sanger sequencing of near full-length imp amplicons using DNA extracts of representative samples from 2015 (data not shown), including the 2014 and 2015 samples used in multilocus sequence analysis, revealed a perfect match of the imp primers and probe into all isolates. Taken together, these results indicate that the final RPA assay system for ' $\mathrm{Ca}$. Phytoplasma pruni' based on imp primers is superior to the $i d p A$ primers and capable of detecting an expanded number of strains of the phytoplasma that occur within Washington orchards, representing the majority, if not all, of the isolates currently present in the state.

Although other taxonomic schemes have been suggested (Arnaud et al. 2007; Botti and Bertaccini 2003; Hodgetts et al. 2008; Lee et al. 2006; Marcone et al. 2000; Perez-Lopez et al. 2016; Shao et al. 2006; Streten and Gibb 2005; Valiunas et al. 2013), the current taxonomic classification of phytoplasma is based on similarity of 16S rRNA sequences and phylogenetic analysis (IRPCM Phytoplasma/Spiroplasma Working Team-Phytoplasma Taxonomy Group 2004), a system that is further supported by using a set of 17 endonucleases to generate RFLP patterns of the 16S rRNA F2nR2 fragment (Lee et al. 1993, 1998). Another alternative to the generation of in vitro RFLP patterns is the validation of computersimulated in silico RFLP patterns (Wei et al. 2007, 2008) that culminated in the development of $i$ PhyClassifier, an interactive online phytoplasma classification tool (Zhao et al. 2009). Using these three criteria (similarity coefficient, phylogeny, and in silico $i$ PhyClassifier RFLP pattern generation), we showed that three distinct isolates of ' $\mathrm{Ca}$. Phytoplasma pruni' make up a novel subgroup within the 16 SrIII group. This conclusion is further supported by phylogenetic analyses from four additional coding regions ( $\sec Y, \operatorname{rpoE}, i d p A$, and imp) of the phytoplasma. Notably, whereas the $i d p A$ and 16S rRNA phylograms grouped the novel strain of ' $\mathrm{Ca}$. Phytoplasma pruni' within the 16SrIII-H subgroup, the imp phylogram placed the novel strain with the 16 SrIII-F subgroup. This result corroborates a previous finding on the lack of correlation between sequence identities of imp and those of $16 \mathrm{~S}$ rRNA gene in several phytoplasmas, further supporting the proposition that some factors other than evolutionary time contribute to the variability of immunodominant protein (Morton et al. 2003). Future studies involving additional characterization of the novel ' $\mathrm{Ca}$. Phytoplasma pruni' strain described in this study will provide more insights on the evolutionary significance of this finding.

It is worthwhile to note that, because source trees of the three novel strains of ' $\mathrm{Ca}$. Phytoplasma pruni' were already removed in the orchard even before their full identification, it was not possible to obtain materials for maintenance of the isolate in the greenhouse. Nonetheless, the unraveling of two strains of ' $\mathrm{Ca}$. Phytoplasma pruni' in Washington orchards poses an intriguing question on its placement and/or relationship with historically regarded symptom-designated strains of X-disease phytoplasma on sweet cherry described in California, namely the Green Valley (GVX), Napa Valley (NVX), and Seibe strains (Guerra and Eastwell 2006). The GVX strain, which is considered to be the predominant

TABLE 6. High-throughput sequencing (HTS) and quantitative reverse transcription polymerase chain reaction (qRT-PCR) analysis of RNA expression levels of the two immunodominant protein coding regions, idpA and imp, of 'Candidatus Phytoplasma pruni'

HTS $^{\mathrm{a}}$

\begin{tabular}{|c|c|c|c|c|c|c|c|c|}
\hline \multirow[b]{3}{*}{ Tree sample } & \multirow{2}{*}{\multicolumn{2}{|c|}{$i d p A$}} & \multirow{2}{*}{\multicolumn{2}{|c|}{$i m p$}} & \multirow{2}{*}{\multicolumn{2}{|c|}{$i d p A$}} & \multirow{2}{*}{\multicolumn{2}{|c|}{ imp }} \\
\hline & & & & & & & & \\
\hline & Counts $^{\mathrm{b}}$ & $\mathrm{RPK}^{\mathrm{c}}$ & Counts $^{\mathrm{b}}$ & $\mathrm{RPK}^{\mathrm{c}}$ & $\mathrm{C}_{\mathrm{T}}{ }^{\mathrm{d}}$ & Copies per nanogram plant $\mathrm{RNA}^{\mathrm{e}}$ & $\mathrm{C}_{\mathrm{T}}{ }^{\mathrm{d}}$ & Copies per nanogram plant $\mathrm{RNA}^{\mathrm{e}}$ \\
\hline $10-1$ & 220 & 255 & 2,147 & 4,043 & 22.86 & 544.86 & 19.91 & $14,223.19$ \\
\hline $13-1$ & 84 & 97 & 427 & 804 & 24.28 & 483.98 & 23.47 & $3,505.33$ \\
\hline $15-1$ & 192 & 222 & 2,051 & 3,862 & 23.20 & 856.1 & 21.22 & $12,194.77$ \\
\hline $15-4$ & 292 & 338 & 3,764 & 7,088 & 22.76 & $1,070.29$ & 19.94 & $25,198.94$ \\
\hline Average & 197 & 228 & 2,097 & 3,950 & 23.27 & 738.80 & 21.13 & $13,780.56$ \\
\hline
\end{tabular}

${ }^{a}$ For HTS, no read counts for $i d p A$ and imp coding regions were recovered from the noninfected tree sample (sweet cherry cultivar Bing on cultivar Mazzard seedling rootstock). Negative control templates (water and total RNA from greenhouse-grown sweet cherry 'Bing' on 'Mazzard' seedling rootstock) used in qRTPCR did not result in amplification.

${ }^{\mathrm{b}}$ Counts refer to the number of reads mapping to each coding region.

c Reads per kilobase (RPK) values were calculated using the formula: counts/(nucleotide length of each coding region/1,000); the nucleotide lengths of $i d p A$ and imp coding regions are 864 and 531 nucleotides, respectively.

$\mathrm{d}$ The $\mathrm{C}_{\mathrm{T}}$ value for each coding region of each tree sample was derived from the average of three replicates. Standard deviation values of $0.026,0.046,0.015$, and 0.021 for $i d p A$ and $0.076,0.020,0.091$, and 0.090 for imp were computed for the 10-1,13-1, 15-1, and 15-4 tree samples, respectively.

e The number of copies per nanogram of plant RNA for each coding region of each tree sample was derived from the average copies from three replicates of each coding region $\left(7.47 \times 10^{4}, 2.72 \times 10^{4}, 5.89 \times 10^{4}\right.$, and $8.07 \times 10^{4}$ for idpA and $1.95 \times 10^{6}, 1.97 \times 10^{5}, 8.39 \times 10^{5}$, and $1.90 \times 10^{6}$ for imp were computed averages of tree samples 10-1, 13-1, 15-1, and 15-4, respectively) divided by the amount of total RNA of each tree sample. 
strain in California, closely resembles the predominant strain in Washington based on fruit symptomatology (small fruits produced from infected trees with markedly reduced fruit stem length). Whether the novel strain described here corresponds to NVX or Seibe strains or is entirely distinct is an interesting area for future research.

During the initial stages of RPA development, the $i d p A$ region was preferentially selected over the imp region for additional evaluation despite comparable detection capability of the two primers. This was based on the assumed status of IdpA as the major immunodominant protein of the ' $\mathrm{Ca}$. Phytoplasma pruni' 16SrIII-A subgroup (Blomquist et al. 2001). The change in the RPA target region from $i d p A$ to $i m p$ prompted reexamination of expression levels of both immunodominant proteins from our initial HTS data (from 10-1 tree). The higher expression values of imp over idpA in both HTS and qRT-PCR were unexpected. Although these differences were not statistically significant, the $P$ values for both HTS and qRT-PCR comparisons were close to the minimum accepted value of 0.05 , and the expression values of $i d p A$ and imp showed similar trend in all samples. The lack of statistical significance between expression values of imp and idpA is attributed to the variation observed in sample 13-1. Variability is also anticipated, because the samples originated from commercial orchards rather than controlled environments. Although the previous work showed protein expression of IdpA (Blomquist et al. 2001), data on comparative protein expression analysis between IdpA and Imp have not been shown. The Imp protein and its function have only been predicted based on its relative location within the genome (identical genes spanning the putative $i m p$ with other phytoplasmas) and sequence similarity with other Imp proteins of other phytoplasmas (Liefting and Kirkpatrick 2003). Here, it is shown that the expression of imp, albeit only at the transcript level, is $\sim 20$ fold higher than the corresponding $i d p A$ of 16SrIII-A strain of ' $\mathrm{Ca}$. Phytoplasma pruni'. These results corroborate similar trends observed in the poinsettia branch-inducing phytoplasma subgroup, 16SrIII-H, of ' $C a$. Phytoplasma pruni' (Neriya et al. 2011) at the protein level. Additional experimentation on actual protein expression and accumulation between the two coding regions is required to confirm their relative importance in determining immunological characteristics. Additionally, because imp is also a very highly expressed transcript in comparison with other coding regions of the phytoplasma, there exists a potential for further increasing sensitivity of the RPA assay developed in this study by incorporating a reverse transcription step.

\section{ACKNOWLEDGMENTS}

We thank L. Guerra for providing the peach yellow leafroll isolate of 'Ca. Phytoplasma pyri' and J. Mgbechi-Ezeri for providing an isolate of Pseudomonas syringae pv. syringae.

\section{LITERATURE CITED}

Arnaud, G., Malembic-Maher, S., Salar, P., Bonnet, P., Maixner, M., Marcone, C., Boudon-Padieu, E., and Foissac, X. 2007. Multilocus sequence typing confirms the close genetic interrelatedness of three distinct flavescence dorée phytoplasma strain clusters and group $16 \mathrm{SrV}$ phytoplasmas infecting grapevine and alder in Europe. Appl. Environ. Microbiol. 73:4001-4010.

Blomquist, C. L., Barbara, D. J., Davies, D. L., Clark, M. F., and Kirkpatrick, B. C. 2001. An immunodominant membrane protein gene from the Western $\mathrm{X}$-disease phytoplasma is distinct from those of other phytoplasmas. Microbiology 147:571-580.

Botti, S., and Bertaccini, A. 2003. Variability and functional role of chromosomal sequences in 16SrI-B subgroup phytoplasmas including aster yellows and related strains. J. Appl. Microbiol. 94:103-110.

Davis, R. E., Zhao, Y., Dally, E. L., Lee, I.-M., Jomantiene, R., and Douglas, S. M. 2013. 'Candidatus Phytoplasma pruni', a novel taxon associated with $\mathrm{X}$-disease of stone fruits, Prunus spp.: Multilocus characterization based on
16S rRNA, secY, and ribosomal protein genes. Int. J. Syst. Evol. Microbiol. 63:766-776.

Deng, S., and Hiruki, D. 1991. Amplification of 16S rRNA genes from culturable and nonculturable mollicutes. J. Microbiol. Methods 14:53-61.

Douglas, S. M. 1986. Detection of mycoplasma-like organisms in peach and chokecherry with X-disease by fluorescence microscopy. Phytopathology 76:784-787.

Edgar, R. C. 2004. MUSCLE: Multiple sequence alignment with high accuracy and high throughput. Nucleic Acids Res. 32:1792-1797.

Granett, A. L., and Gilmer, R. M. 1971. Mycoplasmas associated with Xdisease in various Prunus species. Phytopathology 61:1036-1037.

Guerra, L. J., and Eastwell, K. C. 2006. Phytoplasma in deciduous fruit and nut trees. Pages 93-136 in: Characterisation and Identification of Phytoplasmas. N. A. Harrison, G. P. Rao, and C. Marcone, eds. Studiom Press, Houston, TX.

Hall, T. A. 1999. BioEdit: A user-friendly biological sequence alignment editor and analysis program for Windows 95/98/NT. Nuclcei Acids Symp. Ser. 41:95-98.

Hodgetts, J., Boonham, N., Mumford, R., Harrison, N., and Dickinson, M. 2008. Phytoplasma phylogenetics based on analysis of secA and 23S rRNA gene sequences for improved resolution of candidate species of 'Candidatus Phytoplasma'. Int. J. Syst. Evol. Microbiol. 58:1826-1837.

IRPCM Phytoplasma/Spiroplasma Working Team-Phytoplasma Taxonomy Group. 2004. 'Candidatus Phytoplasma', a taxon for the wall-less, nonhelical prokaryotes that colonize plant phloem and insects. Int. J. Syst. Evol. Microbiol. 54:1243-1255.

Jones, A. L., Hooper, G. R., and Rosenberger, D. A. 1974. Association of mycoplasmalike bodies with little peach and X-disease. Phytopathology 64: $755-756$

Kakizawa, S., Oshima, K., Ishii, Y., Hoshi, A., Maejima, K., Jung, H. Y., Yamaji, Y., and Namba, S. 2009. Cloning of immunodominant membrane protein genes of phytoplasmas and their in planta expression. FEMS Microbiol. Lett. 293:92-101.

Kappagantu, M., Bullock, J. M., Nelson, M. E., and Eastwell, K. C. 2017a. Hop stunt viroid: Effect on host (Humulus lupulus) transcriptome and its interactions with hop powdery mildew (Podospheara macularis). Mol. Plant-Microbe Interact. 30:842-851.

Kappagantu, M., Villamor, D. E. V., Bullock, J. M., and Eastwell, K. C. 2017 b. A rapid isothermal assay for the detection of Hop stunt viroid in hop plants (Humulus lupulus), and its application in disease surveys. J. Virol. Methods 245:81-85.

Kirkpatrick, B. C., Fisher, G. A., Fraser, J. D., and Purcell, A. H. 1990. Epidemiology and phylogenetic studies on western X-disease mycoplasmalike organisms. Pages 288-297 in: Recent Advances in Mycoplasmology. G. Stanek, G. H. Cassell, J. G. Tully, and R. F. Whitcomb, eds. Gustav Fischer Verlag, Stuttgart, Germany.

Kumar, S., Stecher, G., and Tamura, K. 2016. MEGA7: Molecular Evolutionary Genetics Analysis, Version 7.0. for Bigger Datasets. Mol. Biol. Evol. 33:1870-1874.

Larsen, K. J., and Whalen, M. E. 1988. Dispersal of Paraphlopsius irroratus (Say) (Homoptera: Cicadellidae) in peach and cherry orchards. Environ. Entomol. 17:842-851

Lee, I.-M., Bottner-Parker, K. D., Zhao, Y., Davis, R. E., and Harrison, N. A. 2010. Phylogenetic analysis and delineation of phytoplasmas based on secY gene sequences. Int. J. Syst. Evol. Microbiol. 60:2887-2897.

Lee, I.-M., Gundersen, D. E., Davis, R. E., and Chiykowski, L. N. 1992. Identification and analysis of a genomic strain cluster of mycoplasmalike organisms associated with Canadian peach (eastern) $\mathrm{X}$ disease, western $\mathrm{X}$ disease, and clover yellow edge. J. Bacteriol. 174: 6694-6698.

Lee, I.-M., Gundersen-Rindal, D. E., Davis, R. E., and Bartoszyk, I. M. 1998. Revised classification scheme of phytoplasmas based on RFLP analyses of $16 \mathrm{~S}$ rRNA and ribosomal protein gene sequences. Int. J. Syst. Bacteriol. 48: 1153-1169.

Lee, I.-M., Hammond, R. W., Davis, R. E., and Gundersen, D. E. 1993. Universal amplification and analysis of pathogen 16S rDNA for classification and identification of mycoplasmalike organisms. Phytopathology 83: 834-842.

Lee, I.-M., Zhao, Y., and Bottner, K. D. 2006. SecY gene sequence analysis for finer differentiation of diverse strains in the aster yellows phytoplasma group. Mol. Cell. Probes 20:87-91.

Liefting, L. W., and Kirkpatrick, B. C. 2003. Cosmid cloning and sample sequencing of the genome of the uncultivable mollicute, Western X-disease phytoplasma, using DNA purified by pulse-field gel electrophoresis. FEMS Microbiol. Lett. 221:203-211.

MacBeath, J. H., Nyland, G., and Spurr, A. R. 1972. Morphology of mycoplasma-like bodies associated with peach X-disease in Prunus persica. Phytopathology 62:935-937. 
Marcone, C., Lee, I.-M., Davis, R. E., Ragozzino, A., and Seemüller, E. 2000. Classification of aster yellows-group phytoplasmas based on combined analyses of rRNA and tuf gene sequences. Int. J. Syst. Evol. Microbiol. 50: 1703-1713.

Martini, M., Lee, I.-M., Bottner, K. D., Zhao, Y., Botti, S., Bertaccini, A., Harrison, N. A., Carraro, L., Marcone, C., Khan, A. J., and Osler, R. 2007. Ribosomal protein gene-based phylogeny for finer differentiation and classification of phytoplasmas. Int. J. Syst. Evol. Microbiol. 57:2037-2051.

Mcclure, M. S. 1980. Spatial and seasonal distribution of leafhopper vectors of peach X-disease in Connecticut. Environ. Entomol. 9:668-672.

Mekuria, T. M., Zhang, S., and Eastwell, K. C. 2014. Rapid and sensitive detection of Little cherry virus 2 using isothermal reverse transcriptionrecombinase polymerase amplification. J. Virol. Methods 205:24-30.

Morton, A., Davies, D. L., Blomquist, C. L., and Barbara, D. J. 2003. Characterization of homologues of the apple proliferation immunodominant membrane protein gene from three related phytoplasmas. Mol. Plant Pathol. 4:109-114.

Nasu, S., Jensen, D. D., and Richardson, J. 1970. Electron microscopy of Mycoplasma-like bodies associated with insect and plant hosts of peach Western X-disease. Virology 41:583-595.

Neriya, Y., Sugawara, K., Maejima, K., Hashimoto, M., Komatsu, K., Minato, N., Miura, C., Kakizawa, S., Yamaji, Y., Oshima, K., and Namba, S. 2011. Cloning, expression analysis, and sequence diversity of genes encoding two different immunodominant membrane proteins in poinsettia branch inducing phytoplasma (PoiBI). FEMS Microbiol. Lett. 324:38-47.

Perez-Lopez, E., Olivier, C. Y., Luna-Rodriguez, M., and Dumonceaux, T. J. 2016. Phytoplasma classification and phylogeny based on in silico and in vitro RFLP analysis of cpn60 universal target sequences. Int. J. Syst. Evol. Microbiol. 66:5600-5613.

Rawlins, T. E., and Home, W. T. 1931. 'Buckskin', a destructive graft-infectious disease of the cherry. Phytopathology 21:331-335.

Rice, R. E., and Jones, R. A. 1972. Leafhopper vectors of the western Xdisease pathogen: Collections in central California. Environ. Entomol. 1: 726-730.

Rosenberger, D. A., and Jones, A. L. 1978. Leafhopper vectors of the peach $\mathrm{X}$-disease pathogen and its seasonal transmission from chokecherry. Phytopathology 67:277-282.
Shao, J. Y., Jomantiene, R., Dally, E. L., Zhao, Y., Lee, I.-M., Nuss, D. L., and Davis, R. E. 2006. Phylogeny and characterization of phytoplasmal NusA and use of the nusA gene in detection of group 16SrI strains. J. Plant Pathol. 88:193-201.

Skrzeczkowski, L. J., Howell, W. E., Eastwell, K. C., and Cavileer, T. D. 2001. Bacterial sequences interfering in detection of phytoplasma by PCR using primers derived from the ribosomal RNA operon. Acta Hortic. 550:417-424.

Smart, C. D., Schneider, B., Blomquist, C. L., Guerra, L. J., Harrison, N. A., Ahrens, U., Lorenz, K.-H., Seemuller, E., and Kirkpatrick, B. C. 1996. Phytoplasma-specific PCR primers based on sequences of the 16S-23S rRNA spacer region. Appl. Environ. Microbiol. 62:2988-2993.

Stoddard. 1934. Progress report on the investigation of a new peach disease. Proc. Connecticut Pomological Soc. 44:31-36.

Stoddard. 1938. The "X disease" of peach. Circular Connecticut Agric. Exp. Stn. 122:54-60

Streten, C., and Gibb, K. S. 2005. Genetic variation in Candidatus Phytoplasma australiense. Plant Pathol. 54:8-14.

Valiunas, D., Jomantiene, R., and Davis, R. E. 2013. Evaluation of the DNAdependent RNA polymerase $\beta$-subunit gene (rpoB) for phytoplasma classification and phylogeny. Int. J. Syst. Evol. Microbiol. 63:3904-3914.

Wambua, L., Schneider, B., Okwaro, A., Wanga, J. O., Imali, O., Wambua, P. N., Agutu, L., Olds, C., Jones, C. S., Masiga, D., Midega, C., Khan, Z., Jones, J., and Fischer, A. 2017. Development of field-applicable tests for rapid and sensitive detection of Candidatus Phytoplasma oryzae. Mol. Cell. Probes 35:44-56.

Wei, W., Davis, R. E., Lee, I.-M., and Zhao, Y. 2007. Computer-simulated RFLP analysis of 16S rRNA genes: Identification of ten new phytoplasma groups. Int. J. Syst. Evol. Microbiol. 57:1855-1867

Wei, W., Lee, I.-M., Davis, R. E., Suo, X., and Zhao, Y. 2008. Automated RFLP pattern comparison and similarity coefficient calculation for rapid delineation of new and distinct phytoplasma $16 \mathrm{Sr}$ subgroup lineages. Int. J. Syst. Evol. Microbiol. 58:2368-2377.

Zhao, Y., Wei, W., Lee, I.-M., Shao, J., Suo, X., and Davis, R. E. 2009. Construction of an interactive online phytoplasma classification tool, iPhyClassifier, and its application in analysis of the peach X-disease phytoplasma group (16SrIII). Int. J. Syst. Evol. Microbiol. 59:2582-2593. 